\title{
KAJIAN KESESUAIAN KUALITAS AIR UNTUK PENGEMBANGAN KERAMBA JARING APUNG DI PULAU SERANGAN, BALI
}

\author{
N.M. Ernawati ${ }^{1 *)}$, A.P.W.K. Dewi ${ }^{1)}$ \\ ${ }^{1)}$ Prodi Manajemen Sumberdaya Perairan, FKP Universitas Udayana \\ *)E-mail:nimade_ernawati@yahoo.com
}

\begin{abstract}
The marine water area of Serangan Island has been used for several activities such as aquaculture, captured fisheries, ships transportation, tourism and also area for leachate discharge from Suwung waste area. Those activities resulted in the decrease of water quality which has negative effect on the cage net culture activities, especially that low water quality decrease the immune system of the cultured organisms. So far, the feasibility of water quality for cage net culture activity in Serangan Island has not been identified. The objective of this study is to investigate the water quality and its feasibility for the development of cage net culture activity in that area. This study use descriptive and explorative methods to figure out the actual condition of water quality and its feasibility for cage net culture development in marine water area of Serangan Island. Some measured parameters are water depth, current velocity, temperature, salinity, pH, DO, BOD, Ammonia $\left(\mathrm{NH}_{3}-\mathrm{N}\right)$, oil and lipid content, and lead $(\mathrm{Pb})$. The results show that in Serangan Island marine water area, the water quality range as follow: temperature $26-28^{\circ} \mathrm{C}$; Salinity $23-26,67 \mathrm{ppt}$; $\mathrm{pH} 7,4-7,9$; dissolved oxygen (DO) 1,5-6 mg.l $\mathrm{l}^{-1}$; BOD 6,1-8,2 g..$^{-1} ; \mathrm{NH}_{3}-\mathrm{N}$ 0,4-0,9 mg.l $\mathrm{l}^{-1}$; oil and lipid content $<0,1$; lead $(\mathrm{Pb})$ cannot detected $\left(<0,0036 \mathrm{mg} \cdot \mathrm{l}^{-1}\right)$; current velocity $0,2-0,6 \mathrm{~cm} \cdot \mathrm{s}^{-1}$; and the water depth 5,5-9,4 m. Generally, those measured water quality parameters are feasible for marine culture using cage net culture system.
\end{abstract}

Keywords: Cage net culture, Serangan Island marine water, Water quality

\section{PENDAHULUAN}

Pembangunan di bidang kelautan dan perikanan saat ini berkembang sangat pesat dan merupakan kegiatan ekonomi yang sangat strategis untuk mempercepat perkembangan ekonomi masyarakat pelaku perikanan di Indonesia. Pembangunan sektor perikanan dan kelautan sebagai bagian dari Pembangunan Nasional bertujuan untuk mengusahakan agar setiap kegiatan perikanan dan kelautan dapat dilakukan oleh Bangsa Indonesia, baik berkegiatan produksi, pengolahan maupun pemasaran (Dahuri dkk., 2004).

Pengembangan usaha perikanan di Indonesia memiliki peluang yang masih sangat besar, hal itu dikarenakan pemanfaatan perairannya yang sampai saat ini masih relatif rendah. Ditjen Perikanan (2008) menyatakan bahwa pemanfaatan potensi sumberdaya ikan di laut baru mencapai $65 \%$, atau baru 4,8 juta ton per tahun dari potensi sumberdaya ikan yang mencapai 6,4 juta ton per tahun. Sementara itu, kondisi global juga menyediakan peluang besar bagi pengembangan perikanan yang ditunjukkan antara lain oleh terus meningkatnya permintaan terhadap ikan dan produk perikanan, berubahnya pola makan dari daging merah (red meat) ke daging putih (white meat), gaya hidup yang lebih berorentasi pada makanan yang nonkolesterol dan lain sebagainya (Effendi, 2004 dan Cholik et al., 2005).

Usaha pemanfaatan sumberdaya perairan umum bagi usaha budidaya ikan, yang kini digiatkan adalah usaha budidaya dalam keramba jaring apung (floating net). Prospek budidaya ikan dalam kantong jaring apung ini cukup cerah, mengingat Indonesia dikelilingi oleh perairan sehingga akan memberikan peluang yang semakin besar bagi para petani ikan atau masyarakat yang ingin memanfaatkan perairan tersebut untuk budidaya dalam kantong jaring apung (Saputra, 1998). Di sisi lain kegiatan budidaya perikanan harus tetap memperhatikan kelestarian sumberdaya dan lingkungan guna mewujudkan kawasan budidaya yang berkelanjutan (Tiskiantoro, 2006).

Perairan Pulau Serangan banyak dimanfaatkan untuk berbagai kegiatan, antara lain sebagai daerah perikanan tangkap dan budidaya, pelabuhan kapal PT Pelni, kapal tradisional, kapal perikanan tangkap, jalur transportasi laut, tempat rekreasi dan olahraga, tempat kawasan industri pariwisata, pemukiman penduduk, serta industri perikanan. Selain itu perairan Pulau Serangan juga merupakan muara dari dua sungai, yakni Tukad Badung dan Tukad Sidekarya, serta menjadi lokasi pembuangan limbah ke laut dari aktivitas pengolahan limbah domestik DSDP dan lindi dari TPA Suwung. 
Gambaran berbagai kegiatan tersebut memperlihatkan bahwa Perairan Pulau Serangan sangat rawan akan terjadinya penurunan kualitas air dan pencemaran. Sejauh ini belum diketahui tentang kesesuaian kualitas air untuk budidaya di perairan tersebut. Oleh karena itu perlu dilakukan suatu kajian tentang kualitas air di perairan Pulau Serangan sebagai kajian awal untuk pengembangan kegiatan budidaya dalam keramba jaring apung (KJA) di perairan tersebut.

\section{METODOLOGI}

Metode yang digunakan dalam penelitian ini adalah metode survey. Titik-titik sampling ditetapkan menggunakan metode purposive.Pengambilan data parameter kualitas air dilakukan sebanyak 2 kali yaitu pada saat pasang dan saat surut. Pengukuran parameter kualitas air dilakukan dengan 2 cara yaitu insitu dan eksitu (analisis di laboratorium).

Data yang dikumpulkan dalam penelitian ini terdiri dari kedalaman, kecerahan, kecepatan arus, suhu, salinitas, $\mathrm{pH}$, oksigen terlarut (DO), BOD dan logam timbal $(\mathrm{Pb})$. Data kedalaman, kecerahan, kecepatan arus, suhu, salinitas, $\mathrm{pH}$, oksigen terlarut (DO) diperoleh dari hasil pengukuran di lapangan (insitu), sedangkan data BOD dan logam timbal $(\mathrm{Pb})$ diperoleh dari hasil analisis laboratorium.
Alat-alat yang digunakan dalam penelitian antara lain alat-alat pengukur kualitas air dan alatalat penunjang seperti GPS dan perahu. Alat-alat yang diperlukan secara rinci dapat dilihat pada Tabel 1. Sedangkan bahan yang digunakan dalam penelitian antara lain tissue dan aquades untuk membersihkan peralatan.

Tabel 1. Alat-Alat yang Digunakan dalam Penelitian

\begin{tabular}{lll}
\hline Parameter & Alat / Metode & Keterangan \\
\hline Suhu & Thermometer Hg & Insitu \\
Salinitas & Refraktometer/pembaca skala & Insitu \\
$\mathrm{pH}$ & $\mathrm{pH}$ meter & insitu \\
$\mathrm{DO}$ & DO Meter & Insitu \\
Kecepatan arus & Current meter & Insitu \\
Kedalaman perairan & Deepscan & Insitu \\
BOD & Titrimetri & Laboratorium \\
Amonia Bebas $\left(\mathrm{NH}_{3}-\mathrm{N}\right)$ & Nessler & Laboratorium \\
Minyak dan Lemak & Gravimetri & Laboratorium \\
Logam Timbal $(\mathrm{Pb})$ & AAS & Laboratorium \\
\hline
\end{tabular}

Data-data yang diperoleh dari observasi lapangan maupun data-data pelengkap dianalisis secara statistik deskriptif menggunakan program excel for windows untuk menggambarkan kondisi kualitas air saat itu di lokasi penelitian.

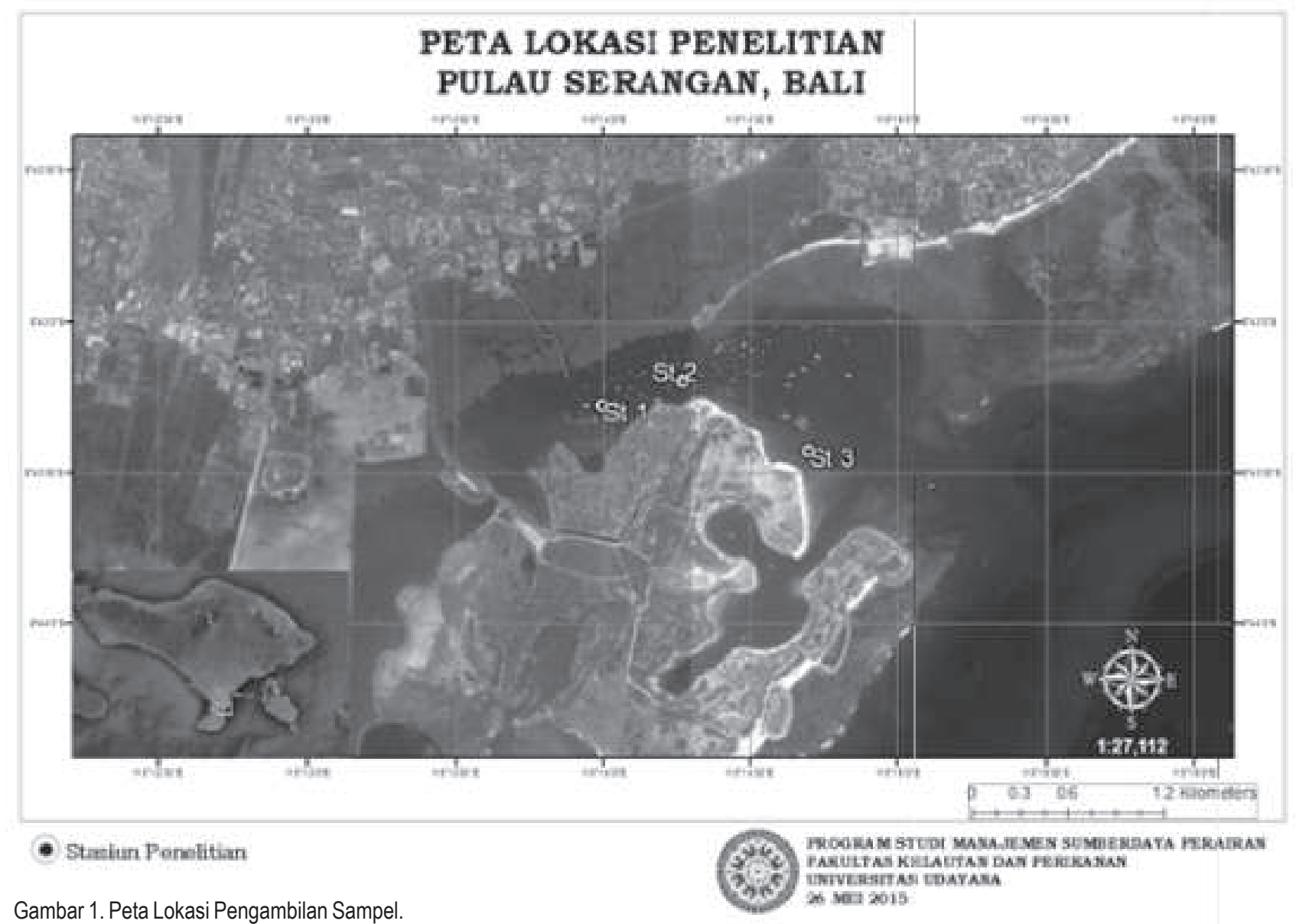




\section{HASIL DAN PEMBAHASAN}

\subsection{Kondisi Umum Lokasi Penelitian}

Pulau Serangan merupakan salah satu pulau kecil yang ada di Provinsi Bali yang hanya dihubungkan oleh sebuah jembatan. Secara administratif Serangan merupakan salah satu kelurahan di Kecamatan Denpasar Selatan yang terletak di sebelah Selatan Pantai Sanur. Luas wilayah Kelurahan Serangan adalah 4,81 km² (481.000 ha), dengan batas wilayah sebagai berikut: Sebelah Utara : Kelurahan Sesetan

Sebelah Selatan : Kelurahan Tanjung Benoa

Sebelah Timur : Kelurahan Sanur

Sebelah Barat : Kelurahan Pedungan

\subsection{Kualitas Air di Sekitar Keramba Jaring Apung}

Pengukuran parameter kualitas perairan di Pulau Serangan dilakukan pada tiga titik lokasi pada saat air laut pasang dan surut. Hasil pengukuran parameter kualitas air ketiga titik sampling menunjukkan perbedaan nilai yang tidak signifikan, perbedaan nilai terlihat pada hasil pengukuran parameter kualitas air pada saat pasang dan surut. Hasil penelitian dari 3 (tiga) titik sampling nilai kisaran masing-masing parameter kualitas air di sekitar KJA Pulau Serangan yaitu : suhu $26-28{ }^{\circ} \mathrm{C}$; Salinitas 23-26,67 ppt; pH 7,4-7,9; oksigen terlarut (DO) 1,5-6 mg/l; BOD 6,1-8,2, g/l; ammonia bebas 0,4-0,9 mg/l; minyak dan lemak <0,1; timbal $(\mathrm{Pb})$ tidak terdeteksi $(<0,036 \mathrm{mg} / \mathrm{l})$; kecepatan arus 0,2 0,6 cm/dt; serta kedalaman perairan 5,5-9,4 m.

Hampir seluruh parameter kualitas air yang diukur mengalami peningkatan konsentrasi pada saat kondisi air pasang, namun tingkat salinitas air mengalami penurunan konsentrasi dengan nilai yang tidak jauh berbeda. Selain salinitas, parameter lain seperti BOD mengalami penurunan konsentrasi pada dua titik lokasi pengamatan yaitu lokasi 2 dan lokasi 3. Demikian pula dengan tingkat ammonia bebas (NH3 N) yang mengalami penurunan konsentrasi saat pasang pada titik lokasi 3. Hasil pengamatan parameter kualitas air pada ketiga titik sampling dapat dilihat pada tabel 2 .

Secara umum, berdasarkan hasil pengukuruan parameter kualitas air tersebut diketahui bahwa kondisi perairan Pulau Serangan sesuai untuk kegiatan budidaya laut dengan sistem KJA. Beberapa parameter kualitas air masuk dalam kategori yang sangat sesuai untuk kegiatan budidaya laut dengan sistem KJA, misalnya parameter suhu, $\mathrm{pH}$ dan kecepatan arus, sedangkan tingkat salinitas, DO, timbal $(\mathrm{Pb}), \mathrm{BOD}$, serta minyak dan lemak berada pada kisaran yang cukup sesuai.

\subsubsection{Suhu Perairan}

Suhu perairan pada ketiga lokasi penelitian berkisar $26-28^{\circ} \mathrm{C}$ sangat sesuai untuk budidaya laut dengan sistem KJA, dimana kisaran suhu yang sesuai untuk budidaya perikanan, rumput laut maupun tiram berkisar antara 28-32 ${ }^{\circ} \mathrm{C}$ (Affan, 2011). Komoditaas perikanan, misalnya ikan akan makan pada waktu pagi dan sore saat suhu air berkisar 27$28{ }^{\circ} \mathrm{C}$ (Kordi, 2005). Suhu sangat mempengaruhi kehidupan dan perkembangan biota laut, peningkatan suhu dapat menyebabkan penurunan kadar oksigen terlarut dalam perairan serta peningkatan konsentrasi karbon dioksida. Keadaan tersebut akan mempengaruhi proses metabolisme dalam tubuh biota laut, misalnya laju pernafasan dan konsumsi oksigen terlarut (Affan, 2012).

\subsubsection{Derajat Keasaman (pH)}

Derajat keasaman $(\mathrm{pH})$ perairan sangat berpengaruh terhadap pertumbuhan dan kelangsungan hidup ikan. Berdasarkan hasil pengukuran $\mathrm{pH}$ pada ketiga titik penelitian dapat disimpulkan bahwa lokasi tersebut sesuai untuk lokasi budidaya laut dengan sistem KJA. Nilai pH terendah terletak pada titik 1 , diduga karena titik 1 berada dekat dengan muara sungai dan paling dekat dengan wilayah pantai dibandingkan dengan kedua titik sampling lainnya. Nilai $\mathrm{pH}$ optimal untuk

Tabel 2. Hasil Pengukuran Parameter Kualitas Air di Perairan Pulau Serangan

\begin{tabular}{|c|c|c|c|c|c|c|c|c|c|c|}
\hline \multirow{2}{*}{$\begin{array}{l}\text { Lokasi } \\
\text { Pengamatan }\end{array}$} & \multicolumn{9}{|c|}{ SURUT } & \multirow[b]{2}{*}{ Kedalaman } \\
\hline & Suhu & Salinitas & $\mathrm{pH}$ & DO & BOD & $\begin{array}{c}\text { Amonia } \\
\text { Bebas (NH3-N) }\end{array}$ & $\begin{array}{c}\text { Minyak } \\
\text { dan Lemak }\end{array}$ & Timbal (Pb) & $\begin{array}{c}\text { Kecepatan } \\
\text { Arus }\end{array}$ & \\
\hline Lokasi 1 & 26,67 & 24,00 & 7,407 & 1,467 & 6,06 & 0,0780 & $<0,1$ & $\operatorname{Ttd}(<0,036)$ & $0,2-0,4$ & 5,5 \\
\hline Lokasi 2 & 27,07 & 26,67 & 7,613 & 3,933 & 8,21 & 0,0432 & $<0,1$ & $\operatorname{Ttd}(<0,036)$ & $0,2-0,4$ & 8,3 \\
\hline Lokasi 3 & 27,50 & 26,00 & 7,903 & 5,867 & 7,07 & 0,1840 & $<0,1$ & $\operatorname{Ttd}(<0,036)$ & $0,2-0,4$ & 8,5 \\
\hline \multirow{2}{*}{$\begin{array}{l}\text { Lokasi } \\
\text { Pengamatan }\end{array}$} & \multicolumn{9}{|c|}{ PASANG } & \\
\hline & Suhu & Salinitas & $\mathrm{pH}$ & DO & BOD & $\begin{array}{c}\text { Amonia } \\
\text { Bebas (NH3-N) }\end{array}$ & $\begin{array}{c}\text { Minyak } \\
\text { dan Lemak }\end{array}$ & Timbal (Pb) & $\begin{array}{c}\text { Kecepatan } \\
\text { Arus }\end{array}$ & Kedalaman \\
\hline Lokasi 1 & 28,87 & 23,00 & 7,687 & 4,067 & 7,21 & 0,9300 & $<0,1$ & $\operatorname{Ttd}(<0,036)$ & $0,3-0,4$ & 6 \\
\hline Lokasi 2 & 28,33 & 24,67 & 7,790 & 5,333 & 6,86 & 0,0540 & $<0,1$ & $\operatorname{Ttd}(<0,036)$ & $0,3-0,6$ & 9,4 \\
\hline Lokasi 3 & 28,10 & 26,33 & 7,927 & 6,017 & 6,48 & 0,0490 & $<0,1$ & $\operatorname{Ttd}(<0,036)$ & $0,2-0,3$ & 9 \\
\hline
\end{tabular}


budidaya laut bervariasi tergantung terhadap jenis biota laut yang akan dibudidayakan, misalnya untuk budidaya ikan dibutuhkan pH 6,5-9,0, dan 7,5-8,5 untuk budidaya rumput laut, serta 6,75-9,0 untuk tiram mutiara (Mayunar dkk., 1995 dalam Affan, 2012). Nilai pH di laut berkisar 7,5-8,4 dan semakin rendah ke wilayah pantai karena dipengaruhi oleh air tawar (Affan, 2012). Pada pH diatas 7, amonia dalam bentuk molekul NH3 akan lebih dominan dari ion $\mathrm{NH} 4$, pada tingkatan tertentu dapat menembus membran sel atau juga menyebabkan rusaknya jaringan insang hiperplasia branchia (Purnomo, 1987).

\subsubsection{Salinitas}

Salinitas pada ketiga lokasi penelitian berkisar 26-28 ppt sudah sesuai karena berada pada kisaran yang optimal untuk budidaya dengan sistem KJA. Salinitas tertinggi terletak pada titik 3 yang diduga karena berada paling jauh dari wilayah pantai sehingga kurang mendapat pengaruh, sedangkan titik 1 terletak paling dekat dengan pantai dimana pada wilayah tersebut terdapat muara sungai. Dengan adanya muara sungai tersebut maka tingkat salinitas perairan menjadi rendah. Namun salinitas untuk budidaya perikanan harus disesuaikan dengan jenis ikan yang akan dibudidayakan karena berbagai jenis ikan memiliki tingkat toleransi terhadap salinitas yang brebeda-beda (Affan, 2012). Dalam budidaya perikanan, salinitas harus stabil atau tidak mengalami fluktuasi (naik-turun) yang besar (Kordi, 2005).

\subsubsection{Oksigen Terlarut/ Dissolved Oxygen (DO)}

Oksigen terlarut (DO) adalah jumlah oksigen terlarut dalam air yang berasal dari fotosintesa dan absorbsi atmosfer/udara. Oksigen terlarut di suatu perairan sangat berperan dalam proses penyerapan makanan oleh mahkluk hidup dalam air. Semakin banyak jumlah DO (dissolved oxygen) maka kualitas air semakin baik. Oksigen terlarut dibutuhkan oleh semua jasad hidup untuk pernapasan, proses metabolisme atau pertukaran zat yang kemudian menghasilkan energi untuk pertumbuhan dan pembiakan. Disamping itu, oksigen juga dibutuhkan untuk oksidasi bahan - bahan organik dan anorganik dalam proses aerobik. Kecepatan difusi oksigen dari udara tergantung dari beberapa faktor seperti kekeruhan air, suhu, salinitas, pergerakan massa air dan udara seperti arcs, gelombang dan pasang surut.

Oksigen terlarut (DO) merupakan faktor pembatas, sehingga jika ketersediannya tidak mencukupi kebutuhan ikan budidaya maka segala aktivitas ikan akan terhambat (Kordi, 2005). Kandungan oksigen terlarut pada lokasi penelitian sudah sesuai untuk kebutuhan budidaya, yaitu berkisar 1-6 ppm. Namun pada lokasi 1 dan 2 kurang memenuhi syarat dikarenakan kandungan oksigen terlarut kurang dari 4 ppm pada saat air surut. Lokasi penelitian pada titik 1 dan 2 merupakan lokasi yang berdekatan dengan pantai, dimana titik 1 berdekatan dengan muara sungai. Salah satu faktor yang dapat menurunkan kandungan oksigen terlarut adalah kenaikan suhu air, respirasi (khususnya malam hari), adanya lapisan minyak di atas permukaan laut dan masuknya limbah organik yang mudah terurai ke lingkungan laut (Hutagalung, 1997 dalam Kangkan, 2006). Menurut Kordi (2005), untuk pertumbuhan ikan-ikan laut dibutuhkan kandungan oksigen terlarut minimal 4 ppm. Sedangkan kandungan optimumnya adalah 5-6 ppm.

\subsubsection{Ammonia Bebas (NH3-N)}

Amonia dalam air ada yang bersifat tidak terionisasi atau amonia bebas (NH3) dan yang mengalami ionisasi (NH4+). Ammonia bebas merupakan senyawa yang bersifat toksik di perairan. Kadar ammonia dalam perairan dapat disebabkan adanya peningkatan proses pembusukan sisa tanaman atau hewan (Sastrawijaya, 2004). Daya racun amonia disebabkan oleh amonia tidak terionisasi (NH3), dan dipengaruhi oleh $\mathrm{pH}$, suhu dan faktor lainnya. Daya racun amonia terhadap organisme perairan akan meningkat jika terjadi penurunan kadar oksigen terlarut, $\mathrm{pH}$ dan suhu.

Kadar ammonia bebas $\left(\mathrm{NH}_{3}-\mathrm{N}\right)$ pada ketiga lokasi penelitian memiliki rentang yang cukup tinggi berkisar 0,04-0,9 ppm. Kadar ammonia bebas tertinggi terletak pada titik 1 sebesar 0,9 ppm pada saat air pasang. Dalam budidaya laut, kadar maksimal ammonia bebas yang diperbolehkan adalah 0,1 ppm (Kordi, 2005). Apabila kadar ammonia bebas di perairan melebihi batas maksimal akan dapat mempengaruhi kelangsungan hidup biota budidaya.

\subsubsection{Biological Oxygen Demand(BOD)}

Biological Oxygen Demand (BOD5) adalah jumlah kebutuhan oksigen yang digunakan oleh organisme perombak untuk menguraikan sejumlah tertentu bahan organik yang ada dalam suatu perairan selama lima hari, yang dinyatakan dalam $\mathrm{mg} / \mathrm{l}$. Semakin tinggi nilai BOD5 maka semakin tinggi bahan organik yang dikandung perairan tersebut untuk diuraikan. BOD5 penting untuk diperhatikan, karena selain menyerap oksigen terlarut dalam air, juga merupakan cerminan keberadaan suatu bahan pencemar organik dalam perairan tersebut.

Pemeriksaan BOD diperlukan untuk menentukan beban pencemar akibat air buangan penduduk atau industri, dan untuk mendesain sistemsistem pengolahan biologis bagi air yang tercemar tersebut. Penguraian zat organik adalah peristiwa alamiah kalau suatu badan air dicemari oleh zat organik. Selama proses penguraian tersebut bakteri dapat menghabiskan oksigen terlarut di dalam air dan mengakibatkan kematian ikan-ikan dan keadaan 

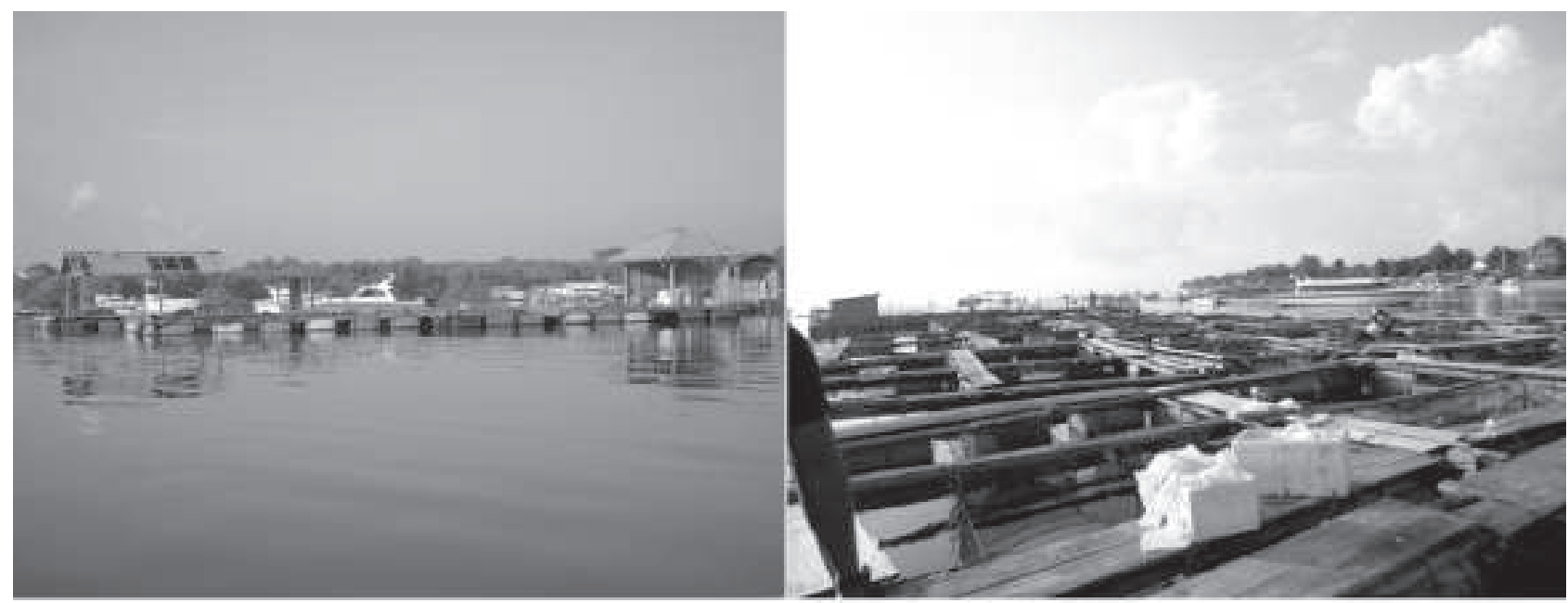

Gambar 3. Kondisi Lalu Lintas Kapal di Sekitar KJA.

menjadi anaerobik, sehingga akan menimbulkan bau busuk (Alaerts, 2001).

\subsubsection{Kecepatan Arus}

Kecepatan arus perairan masuk dalam kategori yang sesuai sebagai lokasi budidaya laut sistem KJA yaitu berkisar 0,2-0,6 m/dt. Kecepatan arus air merupakan parameter kualitas air yang juga menjadi faktor penting dalam budidaya laut. Kecepatan arus yang sesuai sangat dibutuhkan dalam budidaya laut karena arus sangat berperran dalam sirkulasi air, membawa bahan terlarut dan tersuspensi serta mempengaruhi kelarutan oksigen dalam air (Affan, 2011). Apabila arus air terlalu kuat dapat menyebabkan stres pada ikan dan merusak posisi KJA. Kecepatan arus yang sesuai untuk penempatan KJA adalah 0,2-0,5 m/dt (Kordi, 2005). Kecepatan arus perlu diketahui untuk menentukan desain dan konstruksi keramba yang sesuai.

\subsubsection{Kedalaman Perairan}

Kedalaman perairan pada lokasi penelitian menunjukkan nilai yang kurang sesuai namun masih dapat dijadikan sebagai lokasi budidaya dengan sistem KJA karena masih terdapat jarak antara keramba dengan dasar perairan pada saat terjadi air surut. Menurut Kordi (2005) menyebutkan bahwa nilai kedalaman perairan berkisar 7-15 m dari permukaan hingga ke dasar perairan atau kedalam minimal $1 \mathrm{~m}$ dari keramba sampai ke dasar perairan masih layak untuk budidaya laut.

\subsubsection{Lalu Lintas Laut}

Lalu lintas laut merupakan suatu hal yang penting untuk diprtimbangkan dalam pemilihan lokasi budidaya dengan sistem KJA. Kondisi lalu lintas laut disekitar KJA di perairan Pulau Serang cukup ramai sehingga lokasi tersebut kurang sesuai untuk lokasi pengembangan budidaya laut, karena akan mengganggu ketenangan biota budidaya.

\section{SIMPULAN DAN SARAN}

\subsection{Simpulan}

1. Kondisi kualitas air (suhu, salinitas, pH, DO, kecepatan arus, BOD, minyak lemak dan logam timbal (Pb)) Perairan Pulau Serangan secara umum sesuai untukbudidaya laut dengan sistem KJA.

2. Kandungan ammonia bebas, kedalaman perairan serta adanya lalu lintaslaut yang cukup padat di Perairan Serangan kurang sesuai untuk pengembangan KJA.

\subsection{Saran}

Perlu dilakukan penelitian tentang sosial ekonomi masyarakat Pulau Serangan untuk mengetahui minat masyarakat tentang budidaya laut dengan sistem keramba jaring apung (KJA).

\section{DAFTAR PUSTAKA}

Affan, J.M. 2011. Seleksi Lokasi Pengembangan Budidaya dalam Keramba Jaring Apung (KJA) Berdasarkan Faktor Lingkungan dan Kualitas Air di Perairan Pantai Timur Kabupaten Bangka Tengah. J. Sains MIPA, 17(3) : 99-106.

Affan, J.M. 2012. Identifikasi Lokasi untuk Pengembangan Budidaya Keramba Jaring Apung (KJA) Berdasarkan Faktor Lingungan dan Kualitas Air di Perairan Pantai Timur Bangka Tengah. Depik, 1(1) : 78-85.

Agussalim, A., M.R. Ridho, A.G. Susilo. 2011. Pemetaan Kesesuaian Perairan untuk Budidaya Ikan Karamba Jaring Apung (KJA) di Sebagian Pantai Timur Kabupaten Oki Sumatera Selatan. Prosiding Seminar Nasional Tahunan VIII Hasil Penelitian Perikanan dan Kelautan. Jurusan Perikanan Fakultas Pertanian. UGM. Yogyakarta. 
Arikunto, 2010. Prosedur Penelitian : Suatu Pendekatan Praktek (Edisi revisi). PT. Pemuda Cipta. Jakarta. $413 \mathrm{hlm}$.

Cholik F, Jagatraya AG, Poernomo RP dan Jauzi A. 2005. Akuakultur: Tumpuan Harapan Masa Depan Bangsa. Kerjasama Masyarakat Perikanan Nusantara dengan Taman Akuarium Air Tawar TMII. PT. Victoria Kreasi Mandiri. 415 halaman.

Dahuri, R., J. Rais., S. P. Ginting., M. J. Sitepu. 2004. Pengelolaan Sumberdaya Wilayah Pesisir dan Laut Secara Terpadu. Edisi revisi. PT. Pradnya Paramita. Jakarta.

Effendi I. 2004. Pengantar Akuakultur. PT. Penebar Swadaya Jakarta. 187 hal.

Effendi. H. 2003. Telaah Kualitas Air bagi Pengelolaan Sumberdaya dan Lingkungan Perairan. Penerbit Kanisius, Yogyakarta.

Hutabarat, S dan S. M. Evans. 1995. Pengantar Oceanografi. Universitas Indonesia Press, Jakarta.

Ismail W, Imanto PT, Priono B dan Lamidi. 1996. Pemilihan Lokasi Ideal bagi Penempatan Keramba Jaring Apung Reservat Diperairan Kepulauan Riau, Lombok dan Sumbawa. Jurnal Penelitian Perikanan Indonesia, II(4). Edisi Akuakultur. BRKP-DKP. Jakarta.
Kangkan, A.L. 2006. "Studi Penentuan Lokasi untuk Pengembangan Budidaya Laut berdasarkan Parameter Fisika, Kimia dan Biologi di Teluk Kupang, Nusa Tenggara Timur" (Tesis). Program Studi Magister Manajemen Sumberdaya Pantai. Undip. Semarang.

Kordi, K.M.G.H. 2005. Budidaya Ikan Laut di Keramba Jaring Apung. Rineka Cipta. Jakarta

Moleong, J.L. 2002.Metodologi Penelitian Kualitatif. PT. Remaja Rosdakarya. Bandung.

Romimohtarto, K. 2003. Kualitas Air dalam Budidaya Laut. www.fao.org/docrep/field/003.

Saputra, H. 1998. Budidaya Ikan Mas dalam Keramba Jaring Apung. Andi Offset. Yogyakarta.

Satriadi, A dan S. Widada. 2004. Distribusi Muatan Padatan Tersuspensi di Muara Sungai Bodri, Kabupaten Kendal. Jurnal Ilmu Kelautan UNDIP, 9(2) : 101 - 107.

Singarimbun, M. Dan Sofian, E. 1989. Metodologi Penelitian Survey. Lembaga Penelitian, Pendidikan dan Penerangan Ekonomi dan Sosial (LP3ES). Jakarta.

Tiskiantoro, F. 2006. "Analisis Kesesuaian Lokasi Budidaya Karamba Jaring Apung dengan Aplikasi Sistem Informasi Geografis di Pulau Karimunjawa dan Pulau Kemujan” (Tesis). Magister Manajemen Sumberdaya Pantai. Undip. Semarang. 